\title{
Trade Law in a Data-Driven Economy
}

\author{
The Need for Modesty and Resilience
}

Gregory Shaffer

Data, it is said, is the new oil. Treated as a raw material, once processed, once refined, it fuels the new economy. But unlike oil, data is not only nondepletable, it is also constantly generated and exponentially growing. Unlike oil, data exhaust from transactions is not waste but recycled for further use. And unlike oil, data is nonrivalrous as it can be exploited by multiple users. Despite the differences, the metaphor is powerful not only because data fuels the new economy, but also because data is extracted (in this case not only from land but from humans), and because data is protected and traded through law as a new form of property. The value of data vastly surpasses that of oil as measured by the capitalization of the world's largest firms. ${ }^{1}$ The only question for companies is how to gather, store, analyze, and deploy data ever more efficiently since data can significantly reduce transaction and production costs. This chapter examines the social challenges posed by such an economy, their implications for trade law, the current trade negotiating context, and a way forward that can both enhance trade and regulatory efficacy. Section I sets the stage regarding law as a "channeling" tool in the digital economy. Section II examines eight critical challenges. Section III presents the negotiating context in which major powers advance different governance models. Section IV provides a governance framework for moving forward in light of the challenges, a framework that is modest and that foregrounds the importance of building

This chapter is adapted from a keynote presentation at a conference organized by the Asian International Economic Law Network (AIELN) in Taipei, titled "International Trade Regime for the Data-Driven Economy: How Will Artificial Intelligence Transform International Economic Law?". I thank Anne van Aaken, Mira Burri, Jacob Cogan, Monica Hakimi, Alex Huneeus, Christopher Leslie, participants at a workshop at the University of California, Irvine, and participants at the AIELN conference for their comments and questions.

1 Seven of the eight most valuable listed firms in 2019 profit critically from data: Microsoft, Apple, Amazon, Alphabet (parent of Google), Facebook, Alibaba, and Tencent (parent of WeChat). The eighth is Berkshire Hathaway, a holding company whose largest holding is Apple. We pay for the "free" services of Google, Facebook, Alibaba, and WeChat by exchanging access to us and our data. WeChat, owned by Tencent, is the largest social network in China. Facebook envies it in terms of the range of services that WeChat (the "everything app") offers. N Statt and S Liao, "Facebook Wants to Be WeChat" (The Verge, 8 March 2019), https://perma.cc/PBW5-V5QV. 
resilience and engaging in problem solving, learning, and adaptation. Section $\mathrm{V}$ concludes.

\section{THE DATA-DRIVEN ECONOMY AND LAW}

The data-driven economy refers to the collection, aggregation, organization, analysis, exchange, and exploitation of digital information, whether for use in production (such as in "smart manufacturing" and "smart agriculture"), the sale of goods and services (such as through electronic commerce), the provision of services (such as through online platforms like Uber), or trade in data itself (whether for advertising, solicitation, or assessment, such as for credit ratings). ${ }^{2}$ The data-driven economy is fueled by the data generated from connected devices, which is then used to innovate, produce, operate, and sell responsive machines, goods, and services. ${ }^{3}$ McKinsey estimates that the value of global data flows surpassed that of trade in goods as early as $2014^{4}$

Technology has been and is being developed through the exponential rise in computing power, storage, and bandwidth to exploit data. ${ }_{5} \mathrm{G}$ wireless technology expands capacity, enhances the speed of information flows, reduces latency for nearreal-time communication, and transforms scalability for new services. Data-trained artificial intelligence (AI) industrializes learning, which increases productivity, reduces costs, and improves logistical services, facilitating trade. ${ }^{5}$ Microchips enable

2 OECD, "Exploring Data-Driven Innovation as a New Source of Growth: Mapping the Policy Issues Raised by “Big Data” (2013), https://perma.cc/QX 8-5LT8 (noting data products, data-intensive products, data-driven research and development, data-driven processes, data-driven marketing, and datadriven organization across sectors); A Kusiak, "Smart Manufacturing" (2018) 56 International Journal of Production Research 508-517 "Smart manufacturing is an emerging form of production integrating manufacturing assets of today and tomorrow with sensors, computing platforms, communication technology, control, simulation, data intensive modelling and predictive engineering"); $\mathrm{S}$ Wolfert et al., "Big Data in Smart Farming: A Review" (2017) 153 Agricultural System 69, at 69-80 ("New technologies such as the Internet of Things and Cloud Computing are expected to leverage this development and introduce more robots and artificial intelligence in farming. This is encompassed by the phenomenon of Big Data, massive volumes of data with a wide variety that can be captured, analysed and used for decision-making"). For different definitions of digital trade that vary in their expansiveness, see J Meltzer, "Governing Digital Trade" (2019) 18 World Trade Review 23, at 33 (including those of the World Trade Organization (WTO) Work Program on Electronic Commerce and the U.S. International Trade Commission). Ciuriak and Ptashkina break down digital trade into five modes: D Ciuriak and M Ptashkina, "The Digital Transformation and the Transformation of International Trade” (2018), https://perma.cc/M2SS-4SJN.

3 D Ciuriak, "The Economics of Data: Implications for the Data-Driven Economy," in Data Governance in the Digital Age: Special Report (2018), at 12.

4 McKinsey Global Institute, "The Internet of Things: Mapping the Value Beyond the Hype" (2015), https://perma.cc/PZ2A-EF 7 B; J Manyika and M Chui, "By 2025, Internet of Things Applications Could Have U.S. 11 Trillion Impact” (Fortune, 22 July 2015), https://perma.cc/93VS-UNC9.

5 D Ciuriak, "Digital Trade: Is Data Treaty-Ready?" (2018) CIGI Papers No. 162. AI can reduce transport, storage, and logistics costs by optimizing production and route planning and reducing uncertainty of delivery times. It can facilitate localized manufacturing through $3 \mathrm{D}$ printing. These costs represent a major share in overall trade costs, and therefore their reduction can have a large 
powerful computers at our fingertips, generating new data to be processed. "Smart" manufacturing self-automates, trumpeted in Germany as "Industry 4.0" and in the United States as the "Industrial Internet." Linking big data, cloud computing, wireless sensor networks, and automated analytic tools with industrial equipment, it makes manufacturing more efficient, more precise, and more responsive. ${ }^{6}$ Daily life - from driverless cars to heart monitors and security locks - revolutionize through the so-called Internet of Things. ${ }^{7}$

Many if not most commentators on trade and technology are technological optimists since, in basic economic theory, "technological progress by definition shifts out the production possibilities frontier" and thus enhances aggregate social welfare. ${ }^{8}$ Basic trade law and economics casebooks deploy parables that compare trade with technology with a moral that countries should embrace the social welfare benefits of trade. ${ }^{9}$ Even Dani Rodrik, a leading critic of the trade regime for having liberalized too far, has argued that technology is more benign than trade in its distributional effects. ${ }^{10}$

If one is a technology optimist, then our task is less daunting: law should incentivize technology's development and use. Ronald Gilson, writing from Stanford in the nerve center of Silicon Valley, famously called lawyers "transaction cost engineers." ${ }^{\prime \prime}$ It is lawyers who grease the wheels and driverless cars of

impact on trade flows. WTO, "World Trade Report 2018: The Future of World Trade: How Digital Technologies Are Transforming Global Commerce" (2018), https:/perma.cc/Ag8E-N28P, at 8 .

6 McKinsey Global Institute, "The Age of Analytics: Competing in a Data-Driven World" (2016), https://perma.cc/CK95-VY4 $\mathrm{H}$. The characteristics of data-driven smart manufacturing include: (i) the enabling of "customer-centric product development by exploiting user data"; (ii) the enabling of smart production planning by exploiting task data; (iii) the enabling of precise control by exploiting data from the manufacturing process; (iv) the enabling of manufacturing process monitoring through exploiting real-time data; and (v) the enabling of proactive maintenance and quality control by exploiting historical and real-time data. F Tao et al., "Data-Driven Smart Manufacturing" (2018) 48 Journal of Manufacturing Systems 157, at 161.

7 The Internet of Things equips everyday objects, such as thermostats, refrigerators, and coffee machines, with identifying, sensing, networking, and processing capabilities that allow them to communicate with other devices via the Internet to achieve their objectives. See WTO, note 5 above, at 7 .

8 A Korinek and J Stiglitz, "Artificial Intelligence and Its Implications for Income Distribution and Unemployment” (2017) NBER Working Paper 24174, at 21.

9 In the parable, an entrepreneur declares that they have found a way to transform wheat into cars, thereby significantly lowering the cost of production, decreasing the cost of cars for consumers, and increasing standards of living. A competitor, however, discovers that the purported production facilities are in fact empty and that the lower-cost production comes from trading domesticproduced wheat for foreign-produced cars, leading to a public outcry. JHB Pauwelyn et al., International Trade Law (New York, Wolters Kluwer, 2016), at 12-13; and J Ingram, International Economics (New York, John Wiley, 1983).

10 D Rodrik, The Globalization Paradox: Democracy and the Future of Trade Law (New York, W.W. Norton \& Company, 2011), at 59-60.

11 R Gilson, "Lawyers as Transaction Cost Engineers," in P Newman (ed), The New Palgrave Dictionary of Economics and the Law (New York, Stockton Press, 1998), at 509. Compare K Pistor, The Code of Capital: How the Law Creates Wealth and Inequality (Oxford, Princeton University Press, 2019), at 
innovation - the creative disruptor of not just commerce but our life worlds. It is law and lawyers that construct the intangibles of the data-driven economy, such that its potential as energy is released. ${ }^{12}$ Because AI systems require huge quantities of updated data to "train" themselves and continuously learn, improve, and refine their output, the data-driven economy relies on the free flow of data across borders generated from digitized societies. ${ }^{13}$ Predictions made through AI improve with more data, driving its demand. For economic globalization, the "free flow of data" becomes the "fifth freedom" alongside the free movement of goods, services, capital, and labor - the "four freedoms" of the European Union's internal market. ${ }^{14}$

The great contract scholars and rule-of-law theorists stressed law's channeling function. ${ }^{15}$ For the technological optimist, lawyers' role is to free up data flows so as to release pent-up energy for a leap in efficiency, facilitating the making of responsive, just-in-time products adapted to individual and group desires and needs. The challenge of trade law scholars then is to combat constraints on data flows such as data localization requirements that are proliferating, ${ }^{16}$ and new digital taxes, ${ }^{17}$ constituting a new protectionism impeding progress in the digitalized world. The challenge is to press for interoperative standards to ensure frictionless flow across borders and combat fragmentation. The dream is a world where small- and mediumsized enterprises (SMEs) - the Jeffersonian democrats of the marketplace - can compete on a fair footing with the multinational behemoths. ${ }^{18}$ The goal is a terrain where developing country entrepreneurs can better participate and compete

158-182 (chapter 7 on lawyers as "The Masters of the Code," servicing capital's needs); and A Chander, "How Law Made Silicon Valley" (2014) 63 Emory Law Journal 639.

12 Compare W Hurst, Law and the Conditions of Freedom in the 19th Century United States (Madison, WI, University of Wisconsin Press, 1956), at 3 (chapter 1 titles law as "The Release of Energy").

13 D Barton et al., "Artificial Intelligence: Implications for China" (2017), https://perma.cc/98Q5CGUA, at 7; D Ciuriak, "The Knowledge-Based and Data-Driven Economy: Quantifying the Impacts of Trade Agreements" (2017) CIGI Papers No. 156, at 5.

14 Ciuriak, note 5 above, at 9 .

15 L Fuller, "Consideration and Form" (1941) 41 Columbia Law Review 799, at 8o1 (on legal form's "channeling function"); K Llewellyn, "The Normative, the Legal, and the Law Jobs: The Problem of Juristic Method" (1940) 49 Yale Law Journal 1355, at 1376-1383 ("The function includes, to repeat, not only the channeling of overt behavior but the channeling of expectations, norms and claims"); HLA Hart, The Concept of Law (Oxford, Oxford University Press, 1961) (law as "facilitative"); S Shapiro, Legality, (Cambridge, MA, Harvard University Press, 2013) (law as "planning," or planlike norms, that help guide and coordinate action).

16 A Chander and U Lê, "Data Nationalism" (2015) 64 Emory Law Journal 677, at 679.

17 G Hufbauer and Z Lu, "The European Union's Proposed Digital Services Tax: A De Facto Tariff" (2018), https://perma.cc/S9TA-U45 A, at 2. The imposition of digital taxes has become a new subject of trade disputes. Office of the United States Trade Representative, Docket No. USTR-2019-0009, Initiation of a Section 301 Investigation of France's Digital Services Tax (2019); PA Glicklich and H Martin, "Not Whether But When and How: U.S. Response to Unilateral Digital Taxation" (Bloomberg Tax, 30 October 2019), https://perma.cc/W6R3-B898.

18 WTO, note 5 above, at 9 ("The potential decline in trade costs can disproportionately benefit MSMEs and firms from developing countries"); and at 39, 69 (digitalization "leads to a substantial decrease in the cost of entry, making it easier for firms to produce, promote and distribute media products"); J Meltzer, “A WTO Reform Agenda: Data Flows and International Regulatory Cooperation” (2019), 
because deficiencies of physical infrastructure matter less in a world of handheld computers and digitalized communications and services. ${ }^{19}$ The vision is a world of affordable products tailored for individual wants produced in an environmentally sustainable way. ${ }^{20}$ With advances such as $3 \mathrm{D}$ printing, we conceivably could live in a more localized society that would, in the words of Richard Baldwin in his book The Globotics Upheaval, "make for a better society." vantage, is to release the potential of microchips, circuits, and smart machines through the free flow of data. If only government representatives could see policy from the individual consumer's perspective and understand the utilitarian benefits of global markets, the neoclassical trade theorist posits, the world would be more prosperous, more free, and more peaceful.

But if one is not a technology optimist, if one is a pragmatist who believes that there are tradeoffs, if one finds that technology may be unstoppable but there remain choices for governing it, if one is concerned about not just pathologies but also pathogens that law can channel, then what channel should governments choose? In a world of uncertainty, of speculation, amidst the fog of transnational distrust, insecurity, and rivalry, governments face a daunting task.

\section{THE CHALLENGES POSED}

Let us consider eight risks that the technological tsunami of AI could unleash, which are both distinct and interrelated. They are the rise of social inequality and "winnertakes-all” industries, social control through surveillance, risks to democracy, national security threats, economic vulnerability and systemic risk, premature deindustrialization implicating development, geopolitical conflict, and threats to personal privacy and dignity. Although technological change offers great societal benefits, it also raises new regulatory challenges for which responses vary depending on societal contexts and preferences. There is thus reason for pause before concluding ambitious trade agreements that free data flows, at least without significant

https://perma.cc/S6NG-97J9, at 4 ("e-commerce provides a potentially significant opportunity to increase small business participation in international trade").

19 Meltzer, note 18 above, at 9, 11 .

20 WTO, note 5 above, at 32 ("Additive manufacturing is expected to lead to a shift towards more digital and localized supply chains and lower energy use, resource demands and related $\mathrm{CO}_{2}$ emissions over the product life cycle"); M Gebler et al., "A Global Sustainability Perspective on $3 \mathrm{D}$ Printing Technologies" (2014) 74 Energy Policy 158. Additive manufacturing, for example, should reduce wasteful excess production because of its focus on efficiency and just-in-time production. However, maintaining massive amounts of data in the cloud and analyzing it through AI also require large amounts of energy that may come with significant environmental costs. N Jones, "The Information Factories: Data Centres Are Chewing Up Vast Amounts of Energy" (2018) 561 Nature 163, at 163-166.

21 R Baldwin, The Globotics Upheaval: Globalization, Robotics, and the Future of Work (Oxford, Oxford University Press, 2019), at 261. See also V Mayer-Schonberger and T Ramge, Reinventing Capitalism in the Age of Big Data (New York, Basic Books, 2018), at 14 ("Even rich data markets won't be perfect; but pragmatically, they will be far superior to what we have today"); P Barwise, "Nine Reasons Why Tech Markets Are Winner-Take-All” (Think, 10 July 2018), https://perma.cc/BU2P-5M82. 
safeguards. This section examines each of these challenges before the next sections address future trade governance options.

First, the data-driven economy could spur growing inequality in multiple ways, raising social conflict. On the one hand, because of network effects, increasing returns of scale and scope, and the dynamic of first-mover advantage, the datadriven economy increasingly gives rise to winner-takes-all - or winner-takes-most companies, such as Amazon for e-commerce, Google for search engines, and Facebook for social networking. ${ }^{22}$ Companies proficiently using AI can serve additional customers globally at little marginal cost at the same time as they enhance quality, enabling the owner of this form of capital to capture unprecedented rents. ${ }^{23}$ Unlike traditional industries, scale can be increased without the costs of "mass" because data is weightless; its storage is in the cloud. It thus entails near-zero marginal production costs. From this vantage, the trumpeting of e-commerce in terms of how it will benefit SMEs could be a utopian fantasy.

A data-driven economy not only enables economic behemoths to monopolize but also enables them to engage in price discrimination so that they price at what each individual consumer is willing to pay. One of the staple arguments for the benefit of markets in neoclassical economics - that of "consumer surplus" - is thus extracted from individuals since companies have the ability to predict what exactly each consumer is willing to pay and charge that amount. ${ }^{24}$ In addition, AI permits companies to engage in cartel-like behavior through reactive, tit-for-tat responses to coordinate prices, once more to extract rents. ${ }^{25}$ As winner-takes-most companies reap monopoly, oligopoly, and collusive rents, inequality proliferates (including between high- and low-skilled workers). The trade regime is already under considerable stress; simply removing trade barriers to data flows could contribute to social conflict within countries unless growing inequality is addressed.

Second, companies and governments gather data through surveillance that can exploit and shape us. The algorithms they use to process our data enable them to know our future and predict what we want and when we want it better than ourselves. Our wired world creates opportunities for enhanced state control through harnessing social pressure, epitomized by the development of "social credit" systems

22 D Autor et al., "Concentrating on the Fall of the Labor Share" (2017) 107 American Economic Review 180 , at 184 .

23 Ciuriak and Ptashkina, note 2 above, at 9.

24 Consumer surplus represents the difference between the maximum price a consumer is willing to pay and the actual price they pay based on market prices. There are benefits to precision/demand pricing so as to more accurately value goods and services, and thus increase efficiency in matching supply and demand, but such pricing practices also enable companies to extract rents, especially in oligopolistic markets.

25 WTO, note 5 above, at 42,142 . In addition, under this market dynamic, it is harder for niche companies to create profitable niches, which reduces the likelihood that some consumers will be served. Winner-takes-all companies acquire small companies to foreclose competition and, in the process, reduce consumer choice. 
in China. ${ }^{26}$ In parallel, it enables "surveillance capitalists" to steer us toward products to maximize their profits. ${ }^{27}$ Not only can our data be automated, but we can too. When social media become constitutive of social participation, we become increasingly numb to companies and governments knowing everything about us, while we know nothing about how and what they know. ${ }^{28}$ We as consumers are consumed. We participate in our commoditization to fuel trading in data to make the commodities that we buy. It is law that helps constitute that relationship, including through protecting company algorithms through property law. ${ }^{29}$ Law could, for example, ban particular algorithmic practices and otherwise require disclosure and monitoring of algorithms so that they can be contested, whether for different forms of bias or for their social consequences.

Third, the data revolution poses massive problems for democracies. To start, the dynamic of increased economic inequality facilitates conditions for decreased social solidarity and increased social conflict, which can erode democracies. More specifically, the data revolution enables others to manipulate our views, including through the proliferation of "fake news" that harnesses predictive power regarding our psychology and behavior. ${ }^{30}$ Tech developed and harnessed by groups such as Cambridge Analytica relentlessly targets individual vulnerabilities and spurs "thinking fast" tribal responses, thus manipulating behavior to win elections and embed leaders in power. ${ }^{31}$ Foreign authoritarian powers can harness these mechanisms, creating "vast numbers of fake persons orchestrated by shadowy intelligence warfare units building momentum for online paranoia and conspiracy theories." ${ }^{2}$ In addition, entrepreneurs can profit by targeting search results from prior preferences,

26 K Strittmatter, We Have Been Harmonised: Life in China's Surveillance State (London, Old Street Publishing, 2019) ; K Wong and A Dobson, "We're Just Data: Exploring China's Social Credit System in Relation to Digital Platform Ratings Cultures in Westernised Democracies" (2019) 4 Global Media and China 220, at 221.

27 S Zuboff, The Age of Surveillance Capitalism: The Fight for a Human Future at the New Frontier of Power (New York, Public Affairs, 2019), at 8 ("Surveillance capitalism unilaterally claims human experience as free raw material for translation into behavioral data ... fabricated into "prediction products' that are traded in 'behavioral futures markets,' creating incentives 'to herd behavior to profitable outcomes"'); J Cohen, "The Biopolitical Public Domain: The Legal Construction of the Surveillance Economy" (2018) ${ }_{31}$ Philosophy \& Technology 213, at 231 ("a commercial future in which consumer surplus is extracted 'from each according to his abilities,' while goods and services flow 'to each according to his [manufactured] needs"').

28 F Pasquale, The Black Box Society (Cambridge, MA, Harvard University Press, 2016).

29 Pistor, note 11 above, at 129-131.

30 L Diamond, Ill Winds: Saving Democracy from Russian Rage, Chinese Ambition, and American Complacency (New York, Penguin Press, 2019); R Hasen, Election Meltdown: Dirty Tricks, Distrust, and the Threat to American Democracy (New York, Yale University Press, 2020); D Kaye, Speech Police: The Global Struggle to Govern the Internet (New York, Columbia Global Reports, 2019).

${ }^{31}$ J Bartlett, The People vs Tech: How the Internet Is Killing Democracy (New York, Dutton, 2018) at 1 ("In the coming years either tech will destroy democracy and the social order as we know it, or politics will stamp its authority over the digital world").

32 V Buterin and J Lanier, "Foreword," in E Posner and EG Weyl, Radical Markets: Uprooting Capitalism and Democracy for a Just Society (Princeton, NJ, Princeton University Press, 2018), at xxv. 
which divides societies into information bubbles, leading to increased social fragmentation and political polarization. While foreign governments target conspiracy theories at vulnerable groups to create social chaos, entrepreneurs do so to profit from "clickbait." ${ }_{33}$ As Larry Diamond documents, antidemocratic politics are spreading globally. ${ }^{34}$ Democracies risk becoming a shell, unless governments, companies, and societies rise to the regulatory challenge.

Fourth, data and AI pose national security challenges, in part because the refined data and technology have dual uses, giving rise to a shift in trade analysis toward geopolitics and "geoeconomics." ${ }^{5}$ This shift places traditional trade liberals, with their analysis of trade's mutual benefits, on the defensive. At the core of the USAChina trade war is technology, which will determine the global leaders of tomorrow and whether those leaders are Chinese or American. As part of this competition, China competes with the United States, Europe, and Japan in creating standards for the data-driven economy, such as for $5 \mathrm{G}$ infrastructure and the future of manufacturing. The US contestation of China's 2025 innovation initiative, in part, is because China threatens to take the lead in "smart manufacturing" at the cutting edge of technology. Yet that technology also can be used for military purposes. Sales of Huawei ${ }_{5} \mathrm{G}$ infrastructure, for example, become security concerns not only because they facilitate espionage but also because a country's economy can be held hostage under the threat of a shutdown of wireless services. Technology can be "weaponized" by withholding key components in a trade war or in an actual conflict. ${ }^{36}$

Fifth, the technology poses significant systemic concerns regarding the risks of system vulnerability, integrity, and availability. ${ }^{37}$ If the ${ }_{5} \mathrm{G}$ network were to shut

33 C Silverman and L Alexander, "How Teens in the Balkans Are Duping Trump Supporters with Fake News" (BuzzFeed, 3 November 2016), https://perma.cc/9JNN-YJBT; A Higgins et al., "Inside a Fake News Sausage Factory: "This Is All About Income"” (New York Times, 25 November 2016), https:// perma.cc/CF85-JQEQ; N Pelroth, "A Former Fox News Executive Divides Americans Using Russian Tactics" (New York Times, 21 November 2019), https://perma.cc/9UJ6-C2WU.

Diamond, note 30 above.

35 R Blackwill and J Harris, War by Other Means: Geoeconomics and Statecraft (Cambridge, MA, Harvard University Press, 2016) (geoeconomics as the "use of economic instruments to promote and defend national interests, and to produce beneficial geopolitical results"); A Roberts et al., "Toward a Geoeconomic World Order in International Trade and Investment" (2019) 22 Journal of International Economic Law 655 (using the term "to describe a macro level change in the relationship between economics and security in the regime governing international trade and investment").

${ }^{6}$ H Farrell and A Newman, "Weaponized Interdependence: How Global Economic Networks Shape State Coercion" (2019) 44 International Security 42.

37 Engineers refer to three types of risks known as CIA: confidentiality, integrity, and availability. Confidentiality refers to data privacy and security (i.e. unauthorized information release). Integrity refers to the ability of a third party to enter and compromise a program or device, such as a self-driven vehicle, a heart monitor, the electrical grid, or a nuclear power reactor (i.e. unauthorized information modification). Availability refers to the ability to shut down a device or system (i.e. unauthorized denial of use). These three risks are connected and thus referenced in terms of a triangle. For example, a breach of a system's integrity can compromise confidentiality as well as availability. AI, for example, can be very brittle, subject to compromise of its integrity so that a minor tweak can lead to serious malfunction, potentially leading to dire consequences. The CIA triad is codified in the United States 
down without a backup, social chaos could spread, giving rise to a Margaret Atwood MaddAddam dystopia. ${ }^{3}$ Economics, ecology, engineering, and psychology - from their different vantages - all stress the importance of resilience to guard against system collapse, ${ }^{39}$ which the risks of the COVID-19 virus exemplify. The so-called global financial crisis was not in fact global because China and Chinese banks were less ensnared in the market disintegration triggered by the US housing and mortgage-backed securities bubble. Countries could sell their products to China, enabling the global economy to staunch contagion and recover more quickly. Imagine the counterfactual if China's economy had been "just like us" (i.e. the United States) in 2008, with free capital flows and globally integrated banks, and had crashed as well. Because it differed, there was greater resilience for the global economy, benefiting everyone. This experience holds lessons for the risks posed by a global economy dependent on single technological systems, regardless of whether geoeconomic conflict can be managed.

Sixth, the technological revolution can lead to "premature deindustrialization" of developing countries, possibly trapping them at low-income levels in services sectors, widening the global economic divide by a "digital divide." ${ }^{40}$ Development economists worry about the consequences for development since manufacturing helped make many developing countries, particularly in Asia, richer. ${ }^{41}$ With deindustrialization, smart manufacturing enterprises operate more like software companies, requiring employees to design, program, operate, and debug "smart" machines. That know-how will more likely reside in a few leading countries, with the United States, Europe, China, and a few others vying for leadership. In the winner-takes-most economy, large countries that require data localization, such as China, can grant privileged access to their nationals' data to national companies. That is why populous countries such as India, Indonesia, and Brazil envy Chinese Internet companies' fortunes. The calculus for smaller developing countries is less favorable. They most likely benefit from free data flows for foreign companies

Code in 44 U.S.C. $\$ 3552$ (Definitions). Y Cherdantseva and J Hilton, A Reference Model of Information Assurance Security (2013) 2013 Int'l Conf. on Availability, Reliability and Security 546, at 546-555 (2013) (providing a history of the triad); N Kobie, "To Cripple AI, Hackers Are Turning Data Against Itself” (Wired, 11 September 2018), https://perma.cc/5FKF-NZFW.

$3^{8}$ Atwood's MaddAddam trilogy consists of Oryx and Crake (2003), The Year of the Flood (2009), and MaddAddam (2013).

39 R Bhamra et al., "Resilience: The Concept, a Literature Review and Future Directions" (2011) 49 International Journal of Production Research 5375, at 5386, 5393 (noting "the conceptual linkages between vulnerability, resilience and adaptive capacity"); Y Sheff, "Building a Resilient Supply Chain" (2005), https://perma.cc/W6PA-SK8L; J Diamond, Collapse: How Societies Choose to Fail or Succeed (London, Penguin Books, 2011).

$4 \circ$ WTO, note 5 above, at 8 .

${ }^{41}$ Deindustrialization is "premature" because developing countries lose the benefits of manufacturing jobs before "catching up" to the wealth and prosperity of "post-industrialized" nations. D Rodrik, "Premature Deindustrialization" (2015) NBER Working Paper Series No. 20935, at 3. 
serving their constituents, but they will also face foreign monopolists' economic clout.

Seventh, because of rising inequality within countries (which the data-driven economy facilitates), combined with declining inequality between the West and a few emerging powers (notably China with its massive investments in AI and datalinked technology), social conflict both within and between countries could rise. Violence looms, threatening national civic and global peace. For some, the link between the threat of violence and this combination of increasing inequality within countries and decreasing inequality between them may seem paradoxical. Within national contexts, rising domestic inequality increases domestic social conflict. US President Trump's references to the prospect of "civil war" were he to be impeached are symptomatic, ${ }^{42}$ as are the mass protests of the "yellow vest" movement in France. ${ }^{43}$ At the international level, declining inequality between the United States and China threatens US hegemony and, possibly in turn, the stability of the international system to the extent that it depends on one country being hegemonic (per "hegemonic stability theory"). ${ }^{44}$ In parallel, populist leaders harness US and European workers' lost sense of status from the shift of jobs to China and the East, harnessing nationalist fervor. Scholars now warn of the "Thucydides Trap" in which a rising power and an incumbent heedlessly and inescapably march toward war. ${ }^{45}$

Eighth, and finally, there are risks to personal privacy and dignity. We have so far stressed societal risks as opposed to individual ones, as the latter have been most frequently addressed in legal scholarship. ${ }^{6}$ Yet many of these societal risks build on individual ones. Even if societal risks are addressed, the risks to individuals regarding their privacy, dignity, and safety can be ruinous, whether the individual are coerced by authoritarian governments or privately, such as through social media. ${ }^{47}$

42 M McCord, "Armed Militias Are Taking Trump's Civil War Tweets Seriously" (Lawfare, 2 October 2019), https://perma.cc/8KE3-D3TY. As Diamond also writes, "Trump suggested that if his democratically nominated rival, Hillary Clinton, won, the only way to stop her from picking liberal, pro-gun-control judges would lie with 'the Second Amendment people' - a clear reference to gun violence and assassination." Diamond, note 30 above, at 78-79.

43 P Goodman, "Inequality Fuels Rage of 'Yellow Vests' in Equality-Obsessed France" (New York Times, 15 April 2019), https://perma.cc/3NC7-KURS.

44 "Hegemonic stability theory" posits that the international system will be more stable if one country is a dominant power or hegemon, as was the United States following the end of the Cold War. R Gilpin and JM Gilpin, Global Political Economy: Understanding the International Economic Order (Princeton, NJ, Princeton University Press, 2001).

45 G Allison, "The Thucydides Trap: Are the U.S. and China Headed for War?" (The Atlantic, 24 September 2015), https://perma.cc/5V8L-9YSA.

$4^{6}$ See, for example, B Schneier, Data and Goliath: The Hidden Battles to Collect Your Data and Your World (New York, W.W. Norton \& Company, 2015); DJ Solove and PM Schwartz, Information Privacy Law (New York, Wolters Kluwer, 2017); C Kuner, Transborder Data Flows and Data Privacy Law (Oxford, Oxford University Press, 2013).

47 In this vein, Europe (as well as others) has recognized a "right to be forgotten" in recognition of individual privacy and dignity. Google Spain SL, Google Inc. v Agencia Española de Protección de Datos, Mario Costeja González (2014). Compare Daniel Citron, Hate Crimes in Cyberspace (Cambridge, MA, Harvard University Press, 2016). 


\section{THE CURRENT NEGOTIATING CONTEXT}

Trade negotiations often take a mercantilist orientation where trade negotiators aim to protect domestic industries while opening foreign markets. Through the mechanism of reciprocity, these negotiations, complemented by litigation, have led to greater trade liberalization over time. For those focused on reciprocally opening markets, their starting point is no different for data than it is for goods and services how to free up flows, in this case data flows that are intrinsic to the new data-driven economy. In this way, trade law can reduce transaction costs for business and the costs of segmented markets. ${ }^{4}$

Trade scholars have focused on the fit of current trade rules with developments in the new economy, finding the fit wanting. ${ }^{49}$ The same conclusion applies to international law more generally, ${ }^{50}$ rendering the challenges for trade law even greater. Given that World Trade Organization (WTO) rules were negotiated over a quarter of a century ago, before the Internet existed, scholars naturally conclude that trade rules must be updated. WTO rules still address primarily goods, a legacy of the 1948 General Agreement on Tariffs and Trade (GATT), an era where industrial manufacturing represented the commanding heights of the economy. In 1995, with the creation of the WTO and its inclusion of a General Agreement on Trade in Services (GATS), the trade regime partially and indirectly addressed services that are linked to the digital economy, as well as technical regulations affecting trade in goods. ${ }^{51}$ But that too was a quarter of a century ago and technology has changed radically. Today, services constitute the largest and fastest-growing part of the global economy in terms of output, value added, and employment. ${ }^{22}$ The GATS only rudimentarily addresses digital issues where the line between a "good" and a "service" blurs and could eventually disappear. ${ }^{53}$ Not only are an increasing number of goods now inextricably linked with "services" (the Internet of Things),

$4^{8}$ At the WTO ministerial meeting in Buenos Aires in 2018, a group of members issued a Joint Statement on Electronic Commerce to commence negotiations. WTO, Joint Statement on Electronic Commerce, WT/L/1056, 25 January 2019.

49 Meltzer, note 18 above; AD Mitchell and N Mishra, "Data at the Docks: Modernizing International Trade Law for the Digital Economy" (2018) 20 Vanderbilt Journal of Entertainment E Technology Law 1073; M Burri, "The Regulation of Data Flows Through Trade Agreements" (2017) 48 Georgetown Journal of International Law 407.

50 B Kingsbury, "Infrastructure and InfraReg: On Rousing the International Law “Wizards of Is" (2019) 8 Cambridge University Law Journal 171, at 184.

${ }^{51}$ The WTO included a more detailed agreement governing product regulation, the Agreement on Technical Barriers to Trade, but it was drafted before the rise of the data-driven economy and does not address data regulation.

52 P Buckley and R Majmudar, "The Services Powerhouse: Increasingly Vital to World Economic Growth" (Deloitte, 12 July 2018), https://perma.cc/3KZA-E7DM; S Lund et al., "Globalization in Transition: The Future of Trade and Value Chains" (2019), https://perma.cc/9X9F-KSJR, at 109.

53 Mitchell and Mishra, for example, note the limitations of the GATS classification system, and the fact that the main restrictions on Internet-based services are regulatory. Mitchell and Mishra, note 49 above. 
but know-how and data have become the most valuable components of trade across borders. ${ }^{54}$

While WTO negotiations have failed to fill key regulatory gaps for digital trade, countries have negotiated bilateral and plurilateral trade agreements to instill their priorities and values into standards for the digital economy. Trade negotiations reflect competition between systems, since countries' positions reflect their internal policies. One can broadly speak of three distinct approaches for digital governance advanced by the WTO's three most powerful members - the United States, the European Union (EU), and China. ${ }^{55}$

The United States has trumpeted a world of free "data flows" that would benefit its companies. ${ }^{56}$ The United States-Mexico-Canada Agreement, which entered into force on 1 July 2020, illustrates the US approach ${ }^{57}$ Chapter 19 of the agreement is on "Digital Trade," and it represents the first time that a trade agreement has a chapter with such a title. Although this change is, in part, semantic since the chapter borrows significantly from chapter 14 of the earlier Trans-Pacific Partnership (TPP) agreement on "Electronic Commerce," the title signifies a broader concern than trade in goods, and the chapter indeed further tightens rules in favor of US technology companies. It includes provisions mandating free movement of data, a permanent moratorium on customs duties, and bans on data localization requirements, forced disclosure of source codes, and other forced technology transfers. It also includes a new provision providing that Internet platforms should not be held civilly liable for their users' actions, which is modeled on section 230 of the US Communications Decency Act. ${ }^{8}$

Although the EU has advanced liberalization objectives, it imposes significant restraints on the free flow of data on privacy grounds. The EU's position is reflected in its General Data Protection Regulation (GDPR), together with EU judicial oversight of its negotiation of "adequacy decisions" with third countries, such as through "safe harbors" and "privacy shields," in order for data on European citizens to leave the continent. On 16 July 2020, the European Court of Justice invalidated the US-EU Privacy Shield because it provides inadequate protection to EU citizens' privacy from surveillance, just as the court had in October 2015 as regards the

5 Ciuriak and Ptashkina present an excellent table comparing US, EU, and Chinese approaches across issue areas based on the Trans-Pacific Partnership (TPP), the EU-Canada Comprehensive Economic and Trade Agreement (CETA), and the China-Australia Free Trade Agreement. Ciuriak and Ptashkina, note 2 above, at table $A_{1}$ in annex 2.

56 The United States is home to the top ten Internet brands, seven out of the ten Internet companies with the largest market value worldwide, and four US companies provide more than half of the world's cloud computing capacity. SA Aaronson and P Leblond, "Another Digital Divide: The Rise of Data Realms and Its Implications for the WTO” (2018) 21 Journal of International Economic Law 245, at 253.

57 Agreement between the United States of America, the United Mexican States, and Canada (USMCA), chapter 19, 10 December 2019 (entered into force 1 July 2020).

58 Ibid., at art. 19.17; and Communications Decency Act of 1996 \&230, 47 U.S.C. \& 230. 
previous US-EU "Safe Harbor Privacy Principles."59 Because the EU lacks leading digital firms, it is politically easier for it to champion such regulation. ${ }^{60}$

China, in contrast, applies "data localization" requirements on sovereignty grounds, rather than the protection of citizen rights. In this way, the Chinese state and Chinese companies control data over China's 1.4 billion citizens, facilitating social control while creating a competitive advantage for Chinese enterprises. ${ }^{61}$ A result is the rise of Chinese information technology titans such as Alibaba and Tencent.

Other countries choose among these three models, although those "choices" occur within negotiating contexts that can involve highly asymmetric power. In this way, these different models are adopted around the globe. Japan has adopted the US approach, as reflected in the 2019 US-Japan Trade Agreement. ${ }^{62}$ Australia and Canada have hybrid approaches that include stronger data privacy protection as under the EU model, while India, Indonesia, and Brazil are enticed by China's requirements of data localization to create national champions. ${ }^{6}$

A question arises regarding how these models will interface. It is conceivable that the United States and EU could negotiate a further compromise. Although the EU will periodically challenge US tech giants, it unlikely will develop its own. Nonetheless, the EU generally favors a single market for data flows, subject to adequate privacy and consumer protection. The United States and China, however, are less likely to negotiate a compromise (unless it includes significant carveouts on national security and other public policy grounds) given the advantages for China of requiring data localization so that foreign companies do not gain access to the Chinese data trove. India will likely follow this route. ${ }^{64}$ Economic behemoths from just a few countries could dominate the globe. From an economics perspective, the global market will not be based on perfect competition

59 Court of Justice of the European Union Press Release 91/20, The Court of Justice Invalidates Decision 2016/1250 on the Adequacy of the Protection Provided by the EU-US Data Protection Shield (16 July 2020); Case C311/18, Data Prot. Comm'r v. Facebook Ireland Ltd. ECLI:EU:C:2020:559 (16 July 2020).

6o There are no European firms among the top fifteen digital firms by market value, and US firms control some 54 percent of the EU's digital market. Aaronson and Leblond, supra 56 above, at 258 .

61 Mitchell and Mishra, note 49 above. While the United States and European Union have been exporting their approach through free trade agreements (FTAs), Chinese FTAs do not contain binding rules on data flows or language to limit digital protectionism. Rather, China has encouraged e-commerce, a sector where it is very competitive with firms like Alibaba and JD.com. For example, China included provisions for facilitating cross-border e-commerce in its updated FTA with Chile. Ibid., at 268. China is the world's largest digital market, accounts for more than 40 percent of e-commerce transactions, and by 2021 more than half its economy will be digital. Ibid., at 262 .

62 See "Fact Sheet on U.S.-Japan Trade Agreement," Office of the United States Trade Representative (2019), https://perma.cc/SVZ4-JAKJ.

$6_{3}$ Mitchell and Mishra, note 49 above, at 1084-1087.

64 "US Criticises India's Data Localisation Norms, Draft E-commerce Policy" (The Economic Times, 9 April 2019), https://economictimes.indiatimes.com/news/economy/foreign-trade/us-criticises-indias -data-localisation-norms-draft-e-commerce-policy/articleshow/68794927.cms?from=mdr. 
reflected in neoclassical models, but rather "strategic trade" in which a few countries compete to support national champions that reap oligopolistic and monopolistic profits, potentially having positive spillover effects for their national economies.

\section{GOVERNANCE FRAMEWORK FOR A WAY FORWARD:}

\section{A CALL FOR MODESTY}

Although the challenges are severe, if they are to be met, law must play a critical role nationally, internationally, and transnationally. This section provides a framework for addressing the challenges posed. It places trade law in a broader regulatory context that involves competing ways to frame the "problem" to be addressed in a world characterized by uncertainty and rapid technological change. It then applies it to particular issues.

Addressing the challenges requires regulation. Two key issues are: (i) at what level regulation should occur; and (ii) what form and content such regulation should take. In practice, regulation can occur at multiple levels and take different forms, public and private, hard and soft. Moreover, regulation in any one country will have impacts on constituencies outside that country, so that countries have incentives to address these externalities. In parallel, common problems may require regulatory coordination among countries to address it. The key questions thus can be reframed as: (i) What regulation, if any, should occur at the international level and how should it interface with national regulation? (ii) What forms should regulation take and how should these forms interface?

1. Three Governing Principles. To determine a framework for governance of the respective challenges, we start with three principles. First, traditional trade agreements are not optimal for regulatory agreements and thus trade agreements need to be viewed as part of a broader ecology of governance of the new data-driven economy, which creates links between different rule-making and monitoring bodies at different levels of social organization. Second, for most of the issues raised in Section II, there should be no single system of hierarchical rules. Rather, in a world of radical uncertainty and different preferences regarding the regulation of these issues, countries will benefit from experimentation with different regulatory approaches. A diversity of regulatory approaches provides greater resilience against the systemic risks posed when single systems fail. Third, given the transnational impacts of the risks, as well as of national regulation addressing (or failing to address) them, there is a need for systems of regulatory coordination over options and experiences that will facilitate trade while enhancing regulatory efficacy, learning, and adaptation. Once one turns to issues of coordination and the interface of different national regulatory systems, one is in a world of transnational legal ordering that is not just top-down but also bottom-up, horizontal, and transversal. 
Elsewhere I have developed a theory of transnational legal orders with the sociologist Terence Halliday. ${ }^{65}$ That approach focuses on how problems are framed, norms develop transnationally in response to such framings, and norms settle and unsettle as part of recursive processes of interaction between different levels of social organization, from the international to the national and local. That framework has been predominantly positivist in its approach, aimed at generating empirical research for how legal norms develop, diffuse, and change transnationally.

Such an approach, however, also has normative payoffs when combined with what has been called new governance theory regarding systems of adaptive regulation in light of uncertainty involving changing problems and regulatory contexts. New governance theory, when applied transnationally, emphasizes the need for the development of new transnational institutional structures for regulation comprising a common forum for deliberation, principles to guide discussions, an open menu of options for addressing regulatory choices, and peer review and information sharing to enhance trust and learning. ${ }^{66}$ Through such structured processes of regulatory dialogue, both hard and soft international law norms can develop. ${ }^{67}$ The question becomes: How can trade law help to facilitate and channel these processes?

Under a new governance approach, countries jointly create regulatory goals and measures to gauge achievement and permit variation in how regulatory agencies pursue the attainment of these goals. These agencies then report to each other and participate in peer-review processes regarding regulatory outcomes, aimed at continual improvement and potential reassessment of goals in light of experience. ${ }^{68}$ This approach, in the pragmatist tradition, entails ongoing mutual scrutiny of outcomes and their effectiveness based on continuous information exchange by regulators committed to regulatory improvement and attentive to risk, including potentially catastrophic risks. Under this approach, regulators exchange information, conduct joint trials and risk assessments, monitor results, and adapt regulatory

65 T Halliday and G Shaffer, Transnational Legal Orders (Cambridge, Cambridge University Press, 2015).

66 C Sabel and J Zeitlin, "Learning from Difference: The New Architecture of Experimentalist Governance in the EU," in C Sabel and J Zeitlin (eds), Experimentalist Governance in the European Union: Toward a New Architecture (Oxford, Oxford University Press, 2012) (theorizing, describing, and giving examples of new governance mechanisms in the EU); G de Burca and J Scott (eds), Law and New Governance in the EU and the US (Oxford, Hart, 2006), at 2; V Nourse and G Shaffer, "Empiricism, Experimentalism, and Conditional Theory" (2014) 67 Southern Methodist University Law Review 141.

${ }_{67}$ The Organisation for Economic Co-operation and Development (OECD) breaks down the full range of options into eleven approaches that include these regulatory options. See OECD, International Regulatory Cooperation: Rules for a Global World (2012); J Wiener and A Alemanno, "The Future of International Regulatory Cooperation: TTIP as a Learning Process toward a Global Policy Laboratory" (2015) 78 Law \& Contemporary Problems 103.

68 CF Sabel and WH Simon, "Minimalism and Experimentalism in the Administrative State" (2011) 100 Georgetown Law Journal 53, at 55; Nourse and Shaffer, note 66 above. 
practices. ${ }^{69}$ Transparency is central to this model through processes of information sharing, peer review, questioning, and response. Through regulatory learning, norms and practices can recursively change.

At the global level, Charles Sabel and Bernard Hoekman note the possibility of open plurilateral trade agreements that could create frameworks for developing such a regulatory approach. A core group of countries initially would join the agreement, but others could join it subsequently. ${ }^{70}$ In June 2020, Chile, New Zealand, and Singapore signed a Digital Economy Partnership Agreement that aims to develop mechanisms that build trust in data flows, which is open for other parties to join. ${ }^{71}$ More broadly, the United States and EU discussed the development of new transatlantic regulatory mechanisms in their negotiations to create a Transatlantic Trade and Investment Partnership. ${ }^{72}$ The EU proposed the creation of a new transatlantic body, called a Regulatory Cooperation Body, to support specific regulatory cooperation initiatives and oversee them. Hoekman noted how other institutions, including private ones, could complement it in particular regulatory domains. ${ }^{73}$ Through ongoing interactions, national regulators eventually could recognize each other's regulations as functionally equivalent, facilitating trade. These programs could lead to the institutionalization of broader sectoral frameworks, giving rise to cooperative regulatory systems that reduce barriers to trade while enhancing regulatory responsiveness in an increased number of domains. Food safety is one area where such a system has been applied transnationally. ${ }^{74}$ The governance challenges posed by the digital economy beckon for new institutional initiatives in this vein.

New governance theory is particularly useful in a world of radical regulatory uncertainty. Given the risks, uncertainties, and differences in values, interests, and priorities, international trade law must not foreclose experimentation and variance. Yet, given these very same risks, uncertainties, and differences, international trade law and institutions are needed to foster cooperation, deliberation, and exchange of

69 See C Sabel and W Simon, "Contextualizing Regimes: Institutionalization as a Response to the Limits of Interpretation and Policy Engineering" (2012) 110 Michigan Law Review 1, at 18, 20.

70 C Sabel and B Hoekman, "Open Plurilateral Agreements, International Regulatory Cooperation and the WTO" (2019) 10 Global Policy 297. See also B Hoekman and C Sabel, "In a World of Value Chains: What Space for Regulatory Coherence and Cooperation in Trade Agreements," in B Kingsbury et al. (eds), Megaregulation Contested: Global Economic Ordering After TPP (Oxford, Oxford University Press, 2019).

${ }^{71}$ The Digital Economy Partnership Agreement (DEPA) (2019), www.mfat.govt.nz/assets/Uploads/ DEPA-Signing-Text-11-June-2ozo-GMT.PDF.

72 G Shaffer, "Alternatives for Regulatory Governance Under TTIP: Building from the Past" (2016) 22 Columbia Journal of European Law 1.

73 Hoekman, for example, recommended the creation of "knowledge platforms" that bring together "academics, regulators, government agencies, and NGOs." B Hoekman, "Fostering Transatlantic Regulatory Cooperation and Gradual Multilateralization” (2015) 18 Joumal of International Economic Law 609, at 615. He similarly notes the potential role for supply chain councils that would identify regulatory policies that generate unnecessary costs in light of regulatory objectives. Ibid., at 618 .

74 Sabel and Hoekman, note 67 above. 
ideas. International trade law must foster transnational engagement, while not foreclosing regulatory policy space to engage with the challenges posed. Seeking and adjusting the "right" balance between coordination, harmonization, and experimentation will be an ongoing challenge.

2. Electronic Commerce. Regarding electronic commerce, a WTO trade agreement is most achievable if it adopts a decentralized model that accommodates regulatory flexibility in which countries of varying levels of development have different implementation periods conditioned on regulatory capacity building and technical assistance. The WTO's 2017 WTO Trade Facilitation Agreement offers a model of how this can be done. ${ }^{75}$ The Trade Facilitation Agreement provides for flexibility in relation to a country's level of development, and it facilitates provision of technical assistance and resources for developing countries to adapt their regulatory systems. A new digital trade agreement could have a similar structure, in this case organized to accommodate not only countries at different levels of development but also to support the interface and interoperability of different regulatory systems that reflect varying national practices and preferences. ${ }^{76}$ It could establish digital norms to ensure the validity of contracts, recognition of electronic authorizations and signatures, protection against fraudulent practices, and the banning of unsolicited commercial messages. In this way, parties would commit both to foster consumer trust by protecting information and preventing fraud, and to cooperate to tackle transnational problems, such as spam generated from abroad. ${ }^{77}$ Developing country adherence to them, however, would be subject to the receipt of technical assistance, as under the Trade Facilitation Agreement.

These norms could be negotiated and developed in conjunction with other venues, such as before the United Nations Commission on International Trade Law (UNCITRAL), the United Nations Conference on Trade and Development (UNCTAD), the Organisation for Economic Co-operation and Development (OECD), and the $\mathrm{G}_{2} \mathrm{O}$, each of which has ongoing programs to develop, share, assess, and provide capacity building for the adoption of e-commerce regulations. ${ }^{78}$ Though developed elsewhere, the norms could be incorporated by reference into the trade agreement and be updated over time. They could constitute minimum

75 The Trade Facilitation Agreement was concluded at the WTO Ministerial Conference in Bali in December 2013, but it did not enter into force until 22 February 2017. A Eliason, "The Trade Facilitation Agreement: A New Hope for the World Trade Organization” (2015) 14 World Trade Review 643, at 644 .

${ }^{6}$ This also could be addressed through a "reference paper on digital trade," which is attached to a WTO members' schedule of commitments under the GATS, where there is a basic text that provides for variation in members' commitments, analogous to the Trade Facilitation Agreement. M Burri, “Towards a Treaty on Digital Trade" 55 Journal of World Trade 1 (2021, in press).

77 R Wolfe, "Learning about Digital Trade: Privacy and E-Commerce in CETA and TPP" (2019) 18 World Trade Review $6_{3}$.

$7^{8}$ I Lianos et al., "The Global Governance of Online Consumer Protection and E-Commerce, Building Trust” (2019), https://perma.cc/3LLE-GG39. 
standards, while permitting countries to deviate from them on legitimate regulatory grounds. There is precedent for this approach in WTO and other trade agreements. Within the WTO, the Agreement on Sanitary and Phytosanitary Standards references standards developed by Codex Alimentarius and other standard-setting bodies, and the Agreement on Technical Barriers to Trade references international standards more generally, including those developed in the International Organization for Standardization (ISO). More directly on point, in the EU-Canada agreement known as CETA (Comprehensive Economic and Trade Agreement), the parties agree that they "shall take into due consideration international standards of data protection of relevant international organizations of which both Parties are members." 79 In each case, they permit parties to apply more stringent standards for legitimate regulatory reasons.

Such an agreement could also include provisions that are standard in trade agreements. It could require nondiscrimination between domestic and foreign digital products, potentially subject to negotiated product and sectoral carve-outs and general exceptions on regulatory policy grounds, including national security. It could incorporate basic due process commitments, including the right to be heard and to receive reasoned justifications before administrative and judicial processes. It could address (and either ban or otherwise limit) customs duties on electronic transmissions. It could likewise cover the use of digital taxes, possibly, once more, by reference to standards developed elsewhere, whether in the OECD or otherwise. ${ }^{80}$ It also could clarify and enhance parties' market access commitments to services that affect digital trade, which is currently being negotiated in the form of a Trade in Services Agreement on a plurilateral basis among a subset of twenty-three WTO members, including the United States and EU. ${ }^{81}$

Such an agreement could include an ongoing new governance component as well. It could require regulatory transparency and create a framework for

79 Comprehensive Economic and Trade Agreement (CETA), Art. 16.4. Parts of CETA went into provisional effect in September 2017, pending ratification.

8o A trade agreement could incorporate by reference rules on digital taxes developed elsewhere, such as the OECD or G2O. Many developing countries are wary of such liberalization, including the banning of customs duties on electronic transmissions, fearing they will lose revenue and competitiveness. U.N. Conference on Trade and Development, Rising Product Digitilisation and Losing Trade Competitiveness, 15-18, Doc No. UNCTAD/GDS/ECIDC/2017/3 (2017). As for revenue, however, they still could apply nondiscriminatory sales and value-added taxes on such transmissions.

$8_{1}$ For many digital services, it is unclear how they should be classified under the GATS. Burri, note 49 above, at 413-414. Where countries want even greater constraints on data and digital-related regulation, such as prohibiting data localization and source code transfers (subject to possible exceptions, such as on national security and public order grounds), they can address them in bilateral and regional agreements. Even the United States, for example, will wish to retain authority to access source code to guard against money laundering or economics sanctions evasion. See, for example, the Comprehensive and Progressive Agreement for Trans-Pacific Partnership (CPTPP), Art. 14.17; USMCA, Art. 19.16; US-Japan Trade Agreement. On the range of data localization policies that vary in their strictness, see S Sacks and J Sherman, "Global Data Governance" (New America, 16 December 2019), https://perma.cc/3FNT-V8DA, at 8. 
regulators, standard setters, and commercial enterprises to engage with and learn from each other to address the uncertainties that new technologies pose and share information through peer-to-peer processes. ${ }^{82}$ Although WTO committee and working group processes offer one means, ${ }^{83}$ these groups also can work in coordination with other international organizations and standardsetting bodies where the primary regulatory peer review could be done. These latter bodies could then report to the WTO committee. In parallel, bilateral and plurilateral trade agreements can serve as learning laboratories for the development of norms.

3. Cybersecurity and Resilience. To turn to the other challenges raised in Section II, they will be more difficult. For example, concerns over resilience represent a critical reason why a very "ambitious" trade agreement would be problematic at this stage. Governments must be free to regulate and require different standards, product controls, and even product bans, on security grounds to ensure resilience. States and companies will need to develop backup, modular, and exit systems involving redundant and diverse infrastructure that is adaptive to $5 \mathrm{G}$ communications and other breakdowns. ${ }^{8}$ It is a critical question for engineering and for regulatory policy. There are always tradeoffs in product performance and costs, on the one hand, and security, on the other. But here it is not a question of simple market failure and "second-best" government intervention to "correct" it. Rather, the risks can be catastrophic. Regulation of these concerns should thus be left predominantly at the national level, addressed primarily by security and not trade law professionals.

The current GATT Article XXI exception on national security grounds was not drafted with cybersecurity concerns at stake and it will need to be updated to address cyber threats. ${ }^{85}$ The article currently refers to "action ... taken at time of war or other emergency in international relations." National cybersecurity precautions do not neatly fall within this text. It accordingly should be expanded to grant governments greater flexibility to define their security policies in relation to new threats (beyond immediate "emergencies"), while remaining subject to oversight through peer-review mechanisms and (possibly) judicial application of proportionality analysis on a deferential basis. For example, article 17.13 of the Regional Comprehensive Economic Partnership now includes measures "taken so as to protect critical public infrastructure,

82 Sabel and Hoekman, note 70 above.

83 A Lang and J Scott, "The Hidden World of WTO Governance" (2009) 20 EJIL 575, at 58 9.

84 "EU Coordinated Risk Assessment of the Cybersecurity of 5 G Networks Report" (9 October 2019), https://perma.cc/CS9S-FZLG; "Overview of Risks Introduced by ${ }_{5} \mathrm{G}$ Adoption in the United States" (31 July 2019); J-P Kleinhans, "Whom to Trust in a $5 \mathrm{G}$ World? Policy Recommendations for Europe's 5G Challenge" (2019), https://perma.cc/VHA7-ZT9E.

85 For an excellent article on alternative institutional arrangements to address national security issues, see B Heath, "The New National Security Challenge to the Economic Order" (2020) 129 Yale Law Journal 924 . 
including communications, power, and water infrastructures" under the list of legitimate national security concerns. ${ }^{86}$

The bulk of such regulatory efforts must be national where regulators and politicians are most easily held to account. Nonetheless, given the externalities of one country's regulations on others and given reciprocal regulatory concerns, there is a role for regulatory architectures where countries adopting different economic models, holding different preferences, and advancing different interests can cooperate. That calls, on the one hand, for the retention of policy space, including the development of "regulatory sandboxes" to keep up with a rapidly changing digital world in which diverse countries may gain regulatory experience and develop alternative regulatory models. ${ }^{87}$ On the other hand, it calls for the development of new oversight and peer-review mechanisms, together with standard setting, possibly on a voluntary, soft-law basis. Such standard setting and oversight can be allocated between the ISO, the International Electrotechnical Commission, the WTO, and other organizations, catalyzing interlinked networks of institutional oversight and peer review to foster policy learning, cooperation, and coordination.

In a world of increasing geoeconomic competition and accompanying national security concerns, there are limits to what trade agreements can accomplish. Because technological shifts give rise to automated and wirelessly connected products that are vulnerable to hacking, trade in such products acquires a greater security dimension. The US blacklisting of Huawei and other Chinese companies, the banning of the use of Huawei's $5 \mathrm{G}$ technology for their wireless networks by Australia, Japan, New Zealand, and the United Kingdom, and Europe's internal debates exemplify the concerns. In this area, the 2017 US national security plan declares, "economic security is national security." 88 Trade wars and the decline of the rule of law for trade could follow. ${ }^{89}$

And yet, law can be structured to alleviate some of these concerns by facilitating international coordination. To start, rising US concerns over national security suggest that the US position also is shifting toward more expansive exceptions to free data flow commitments. ${ }^{9 \circ}$

86 Regional Comprehensive Economic Partnership, article 17.13. The new USMCA goes further in constraining judicial review, providing that "nothing in this Agreement shall be construed to ... preclude a Party from applying measures that it considers necessary for ... the protection of its own essential security interests." USMCA, article 32.2. As a result, invocation of "essential security interests" is no longer limited to an enumerated list of matters under the USMCA, unlike under GATT Article XXI.

87 Ciuriak, note 3 above, at 7 .

88 "National Security Strategy of the United States of America" (December 2017), https://perma.cc /Q 3 KH-RYTH, at 17 (citing Donald Trump, "Economic security is national security," as epigraph).

89 G Shaffer, "A Tragedy in the Making? The Decline of Law and the Return of Power in International Trade Relations" (2019) 44 Yale Journal of International Law Online 37.

$9 \circ$ For example, the US government is concerned about Chinese companies transmitting data on US consumers back to China. J Nicas et al., "TikTok Said to Be Under National Security Review" 
This shift potentially could facilitate agreement, provided the exceptions are broad enough to encompass privacy and public order interests advanced by the EU, China, and others. In addition, a transnational governance architecture that convenes regulators to address common problems can enhance deliberation, reduce tensions, and thus (indirectly) be more conducive to peace. The approach set forth in this chapter is vastly preferable to the current situation in which trust that underpins a cooperative international trade legal order is eroding.

4. Competition Law. Similarly, policymakers are reevaluating competition policy in response to digitalization and the data-driven economy. ${ }^{91}$ Policy options include regulating property rights in data, ${ }^{92}$ blocking oligopolists' expansion through acquisitions that preempt competition, breaking up companies, and regulating oligopolists like utilities or fiduciaries. ${ }^{93}$ There is considerable debate

(New York Times, 1 November 2019), https://perma.cc/8UZQ-SXAP (noting "evidence of the app sending data to China"). At the WTO, the United States has proposed three categories of exceptions relating to the Joint Statement Initiative on e-commerce: a general exception (which would include public morals and thus privacy); a national security exception; and a prudential/monetary exception. H Monicken, "China’s E-commerce Proposal Includes Privacy Protections, Lacks Data Flow," 37 Inside US Trade 20 (2019).

91 T Philippon, The Great Reversal: How America Gave Up on Free Markets (Cambridge, MA, Harvard University Press, 2019). It is sometimes argued that "the nature of competition in digital markets differs from that in traditional markets as it tends to be based first-and-foremost on innovation rather than pricing," although welfare losses may be high as monopolists become entrenched. R Anderson et al., "Competition Policy, Trade and the Global Economy: Existing WTO Elements, Commitments in Regional Trade Agreements, Current Challenges and Issues for Reflection" (2018) WTO Staff Working Papers ERSD-2018-12, at 47.

92 The legal construct of property rights in data is subject to debate. For example, should data that is generated by user interaction with a product (say, a rented driverless vehicle) be owned by the user, the producer (of the vehicle), or a third-party service provider (such as the rental company, the provider of GPS services, or the provider of insurance)? Should individuals retain ownership rights in their data? Should data be socialized so that large companies are forced to share it with competitors to combat monopolization? Should oligopolistic companies holding data be regulated like utilities? Should governments create state-owned enterprises to profit from citizens' data that the government holds? Or should there be bans on the collection and use of some data so that it does not become property at all? Compare L Weinar, Blood Oil: Tyrants, Violence, and the Rules That Run the World (Oxford, Oxford University Press, 2016) (critiquing the role of property law in legitimizing theft by corrupt leaders of a people's natural resources); and F Pasquale, "The Second Wave of Algorithmic Accountability" (Law and Political Economy Blog, 25 November 2019), https://perma.cc/F $376-5$ GBT (contending that some algorithms should be banned).

93 For example, some propose granting competitive access to data to alleviate consumer "switching costs" of moving from one platform to another, which otherwise lock in consumers. World Trade Report 2018, at 42. Article 20 of the EU's General Data Protection Regulation provides for "data portability" of raw data provided by the data subject, but it likely will have limited impact since the value of data lies in how it has been processed. Regulation 2016/679, of the European Parliament and of the Council of 27 April 2016 on the protection of natural persons with regard to the processing of personal data and on the free movement of such data, and repealing Directive 95/46/EC (General Data Protection Regulation), 2016 O.J. (L 119/1), 68. Nonetheless, government-mandated information sharing will be critical to retain competitive markets. Australia, for example, began consultations on a "mandatory information-sharing scheme between international automakers and Australia's independent repair and service sector" after its national competition authority found that car 
regarding them. ${ }^{94}$ Winner-takes-most companies profit globally through trade, raising tensions between the companies' home countries and third countries regulating them, as in the case of the EU investigating the practices of US data-exploiting multinational companies such as Google. ${ }^{95}$ Countries deploying competition law to discipline foreign companies will continue to trigger trade conflicts. ${ }^{6}$ Given divisions on competition policy, especially between the United States and EU, and given divisions in economic theory, including in relation to the diversity of social contexts, it may be difficult to address this issue in a trade agreement. Nonetheless, the issue calls for dialogue and regulatory response, including within the International Competition Network (ICN), the OECD, and UNCTAD, as well as the WTO's system of committees and working groups. Although the OECD has organized a series of sessions on these issues and the ICN spent its annual meeting in 2019 at Cartagena addressing them, much more work needs to be done regarding the competition law challenges that digitalization poses. ${ }^{97}$

5. Data Privacy. As regards data privacy regulation, countries' approaches again will diverge based on different preferences. Nonetheless, structures can be developed where countries discuss their common concerns and work to free data flows so long as core concerns are met. The European Court of Justice's invalidation of the US-EU Privacy Shield, while upholding the validity of the EU's "standard contractual" clauses for data transfers, illustrates the challenges posed..$^{8}$ Nonetheless, bilateral negotiations, complemented by the development

manufacturers withheld the computerized information from mechanics to favor their dealership networks. N Toscano, "Win for Local Mechanics with Plan to Make World's Car Makers Share High Tech Data" (The Sydney Morning Herald, 12 February 2019), https://perma.cc/YG2X-BANH. See also Mayer-Schonberger and Ramge, note 21 above, at 167-169 (calling for "progressive data sharing").

Compare J Tirole and S Rendall, Economics for the Common Good (Princeton, NJ, Princeton University Press, 2019) (chapters 14 and 15); "What if Large Tech Firms Were Regulated Like Sewage Companies?" (The Economist, 23 September 2017), https://perma.cc/VJZg-2BHM; P Swire, "Should the Leading Online Tech Companies Be Regulated as Public Utilities?" (Lawfare, 2 August 2017), https://perma.cc/BF 4 F-CB6Q; D Ghosh, "Don't Break Up Facebook - Treat It Like a Utility" (2019), https://perma.cc/7XDK-NQFE; G Sitamaran, "Too Big to Prevail: The National Security Case for Breaking Up Big Tech" (Foreign Affairs, March/April 2020), https://perma .cc/NDV $3-66 P_{5}$; J Balkin, "Information Fiduciaries and the First Amendment" (2016) 49 UC Davis Law Review 1183 (treating online companies as fiduciaries of private information, giving rise to fiduciary obligations of care and loyalty); J Balkin and J Zitrain, "How to Exercise the Power You Didn't Ask For" (2018), https://hbr.org/2018/og/how-to-exercise-the-power-you-didnt-ask-for; and Posner and Weyl, note 32 above (chapter 5) (proposing granting stronger rights in data "as labor" so that individuals can extract greater rent from the use of their data).

95 Zuboff, note 27 above, at 134-138.

${ }_{96}$ DJ Gifford and RT Kudrle, The Atlantic Divide in Antitrust: An Examination of US and EU Competition Policy (Chicago, IL, University of Chicago Press, 2015); D Sokol, "Troubled Waters between U.S. and European Antitrust" (2017) 115 Michigan Law Review 955.

97 ICN, "2019 Annual Conference Press Release" (ICN, 17 May 2019), www.internationalcompetitionnet work.org/featured/2019-annual-conference-press-release ("clear focus is on two topics, first, on the digital economy").

$9^{8}$ Court of Justice of the European Union Press Release 91/20, note 61 above; Case C $311 / 18$, Data Prot. Comm'r v. Facebook Ireland Ltd., ECLI:EU:C:2020:559, note 61 above. 
of common international principles and standards, together with ongoing judicial oversight, present a path forward. In practice, jurisdictional conflicts, including the assertion of de facto or de jure extraterritorial jurisdictional power, must be managed continuously. ${ }^{99}$ In these cases, a key challenge for all countries will be how to protect individual information in a world where AI increasingly can identify individuals even when data is processed to be anonymized and deemed "nonpersonal." Given the transnational implications of any policy, and given the role of companies in governing data usage, there is a need not only for governments to develop rules, but also for domestic and transnational civil society organizations to be incorporated within governance mechanisms to engage with governments and corporations. ${ }^{101}$ Once more, structures can be developed outside the WTO for information exchange, peer review, and norm development to address privacy regulation concerns. But the WTO committee system also can be engaged in coordination with such other international bodies.

6. Inequality. Not to be forgotten, societies face rising inequality that the datadriven economy exacerbates. Like trade in goods, free flow of data enhances efficiency and thus welfare gains, but also facilitates economic processes that exacerbate inequality in ways that can threaten social stability and international cooperation. Liberalization of data flows should not be addressed without complementary social policies. For conventional trade theorists, social equality and trade adjustment assistance should be left entirely to the national level. Many reference Scandinavian social welfare and job flexicurity policies to show how this can be done. ${ }^{102}$ Again, such regulatory power should reside predominantly at the national level, which is most democratically legitimate. However, trade agreements can facilitate governments' ability to address social inclusion policies. ${ }^{103}$ At a minimum, trade agreements should not directly or indirectly constrain governments from adopting necessary policies domestically. They must accommodate (and not foreclose) mechanisms that enable states to address labor and other social

G Shaffer and D Bodansky, "Transnationalism, Unilateralism and International Law" (2012) 1 Transnational Environmental Law 31. For example, the European Court of Justice ruled in favor of Google that French rules on the "right to be forgotten" could not be applied to Internet searches conducted outside of the EU. '"Right to be Forgotten' on Google Only Applies in the EU, Court Rules" (The Guardian, 24 September 2019), https://perma.cc/B5SS-SLJ8.

100 L Rocher et al., "Estimating the Success of Reidentifications in Incomplete Datasets Using Generative Models" (2019) 10 Nature Communications 3069 (finding "that 99.98\% of Americans would be correctly re-identified in any dataset using 15 demographic attributes"); see also Chapter 10 in this volume.

101 David Kaye, former UN Special Rapporteur on the Promotion and Protection of the Right to Freedom of Opinion and Expression, stresses this point regarding the regulation of speech in his book Speech Police. Kaye, note 30 above.

102 Flexicurity policies combine labor market flexibility, lifelong learning, active labor market policy, and social security. G Shaffer, "Retooling Trade Agreements for Social Inclusion" (2019) 1 University of Illinois Law Review 17, at 23-24.

103 Ibid., at 17 . 
concerns. ${ }^{104}$ Such agreements also should address (or support addressing) tax evasion and avoidance so that governments can fund social welfare and job flexicurity policies. ${ }^{105}$ These agreements should be developed primarily outside of the WTO. However, since these policies implicate trade, trade liberalization initiatives for the digital economy could be made contingent on their conclusion. Similarly, trade agreements could explicitly recognize the ability of countries to address social dumping concerns, as most recently developed in the United States-MexicoCanada Agreement. ${ }^{106}$ Otherwise, the economic dynamics of trade liberalization in the digital economy could further increase inequality, undercut domestic solidarity, and, in turn, empower nativist and politically populist domestic movements that undermine international cooperation and good will, as well as national democratic systems.

\section{CONCLUSION}

The world needs international institutions to enhance international deliberation, cooperation, and exchange, but international institutions must be careful not to overreach. Normatively, there are efficiency and fairness reasons for agreements to accommodate policy space so that governments may respond effectively to different preferences and priorities. Politically, when international trade law overreaches, it can spur populist backlash so that the system unravels.

The challenges raised in Section II will not be resolved through a traditional trade agreement alone. The data-driven economy is developing at a rapid pace for which governments lack regulatory experience. Given the risks - ranging from systemic risks to risks to democratic institutions, national security, and personal privacy - trade negotiators should proceed with caution and humility. The issues raised are not clearly protectionist, as with tariffs, but rather entail regulation addressing diverse public policy concerns. While one of the purposes of international trade agreements is for national political bodies to "tie themselves to the mast" to avoid the siren call of protectionism, ${ }^{107}$ this rationale is inapt when applied to regulation. Democracies should be able to elect leaders that change orientation regarding the appropriate mix of free data flow and regulation to protect security, privacy, and other concerns. Trade agreements constraining their ability to do so curtail democracy. Because governments weigh tradeoffs regarding the balance between free data flow and other policies in different ways, each country should be free to change its mind. International trade law should not foreclose these domestic debates and choices.

\footnotetext{
104 Ibid., at 33-39.

105 Ibid., at 17-22.

106 Agreement between the United States of America, the United Mexican States, and Canada (entered into force on 1 July 2020), chapter 23.

107 G Maggi and A Rodríguez-Clare, "A Political-Economy Theory of Trade Agreements" (2007) 97 American Economic Review 1374.
} 
At the same time, governance mechanisms are needed in an interdependent world to address common challenges and the externalities that one country's regulations pose for others. Governments should be required to provide equal treatment and due process to affected foreigners domestically, and to provide public policy justifications for the regulations they adopt before transnational peer review and other mechanisms. Section IV advanced a pragmatist, transnational governance architecture focused on regulatory cooperation and learning as an essential complement to WTO "hard" rules backed by dispute settlement. ${ }^{108}$ This form of international governance can interact with national regulation in ways that enhance trade, with its accompanying welfare benefits, as well as regulatory efficacy, learning, and adaptation. It is the best way for trade law to address the challenges raised by the data-driven economy.

The approach set forth in this chapter differs significantly from the "grand bargains" that characterized the creation of the WTO. It is much humbler, grounded in uncertainty regarding the digital world and what it means for societies and individuals. Trade agreements, in turn, should approach the issues with caution, leaving regulation predominantly at the national level, while recognizing common standards in some areas to facilitate trade in goods and services (such as regarding electronic signatures and authorizations), coupled with structures that catalyze experimentation and exchange of knowledge and practices regarding the challenges that all societies will continue to face and to which they must respond. These processes can facilitate learning and, possibly but not necessarily, convergence over time.

There are clear limits to this governance alternative. Commercial interests and countries will contend that there is certainty regarding "best" policies and they will attempt to use leverage and persuasion to extend these policies globally. "Learning" is difficult to facilitate where interests have strong incentives to think otherwise. Yet, even then, such processes will make differences more transparent, while still leaving open the possibility of learning from experience that, potentially, can lead to policy adaptation.

The future can be governed in worse ways or better. Law at the international and national levels and their transnational interaction will help constitute that world. In the face of uncertainty, there is a critical need for agonistic deliberation, debate, and policy experimentation. Karl Polanyi in his book The Great Transformation described what occurred when governments lost control of unleashed markets in the first half of the last century. ${ }^{109}$ We know how that ended. With the data revolution and the rise of $\mathrm{AI}$, the risks are high. The choices societies make today will shape which science fiction remains fiction. It is a brave new world. A future will arrive that we have yet to imagine, but that (hopefully) we can muddle through.

109 K Polanyi, The Great Transformation: The Political and Economic Origins of Our Time (2nd ed., Boston, MA, Beacon Press, 2001). 